Print ISSN: 2288-4637 / Online ISSN 2288-4645

doi:10.13106/jafeb.2020.vol7.no12.073

\title{
Impacts of Corruption Control on Economic Growth in Relationship with Stock Market and Trade Openness
}

\author{
Van Thi Hong PHAM ${ }^{1}$
}

Received: September 01, 2020 Revised: October 26, 2020 Accepted: November 05, 2020

\begin{abstract}
The study aims to investigate the dual effects of corruption control on economic growth in relationship with the stock market and trade openness in developing countries. The study used difference S-GMM method on the dynamic panel data model in the period (2002-2017) with data collected from the World Bank. The study discovers the dominant impacts of corruption control in the relationship with the stock market on economic growth. At the same time, the study also confirms the overwhelming impact of corruption control in the relationship between trade openness and economic growth in the developing countries. In addition, the study shows that inefficient stock markets in developing countries will not promote economic growth. Meanwhile, the long-standing credit market has a positive impact on economic growth. With the strong development of stock market and trade openness in the period (2002-2017), control on corruption in developing countries does not get better in time with the increase in demand. The findings of this study suggest a number of solutions to strengthen corruption control, leading to the increased efficiency on the stock market and as well as encouraging the positive effects of trade openness to contribute to promoting economic growth in developing countries.
\end{abstract}

Keywords: Developing Countries, Economic Growth, Corruption Control, Stock Market Development, Trade Openness

JEL Classification Code: O16, O24, O43, O47

\section{Introduction}

The political institutions in developing nations still concentrate a great deal of power in the public sector on the widespread corruption compared to the richer and developed nations of the world (Olken \& Pande, 2012; Svensson, 2005; Treisman, 2000), which affects development of stock market in particular and economic growth in general (Bolgorian, 2011; Yartey, 2010; Hooper, Sim \& Uppal, 2009). In addition, compared to the developed countries, developing countries account for more than $60 \%$ of the world's population but produce less than $30 \%$ of global GDP (Spence, 2011). As a result, implementing corruption control and developing the stock market to promote economic growth is a top objective for developing countries.

${ }^{1}$ First Author and Corresponding Author. Lecturer, Faculty of Finance and Banking, Van Lang University, Ho Chi Minh City, Viet Nam [Postal Address: 45 Nguyen Khac Nhu Street, Co Giang Ward, District 1, Ho Chi Minh City, 70000, Vietnam] Email: van.pth@vlu.edu.vn

(C) Copyright: The Author(s)

This is an Open Access article distributed under the terms of the Creative Commons Attribution Non-Commercial License (https://creativecommons.org/licenses/by-nc/4.0/) which permits unrestricted non-commercial use, distribution, and reproduction in any medium, provided the original work is properly cited.
With the role of state management, the corruption restrictions of each country must be improved to encourage the positive impacts of the stock market and trade openness on economic growth. Will broad trade openness encourage the economic growth in the context of developing countries with high corruption? Will the regulation of corruption of developing nations promote the development of stock market to meet the economic growth? These are some of the issues which are a top concern for the leaders of the developing countries.

The development of the stock market, which influences economic growth, relies on the degree of progress of the national financial system and the efficiency of the public institutions (Acemoglu \& Robinson, 2010; Duncan, 2014; Talmaciu, 2014). Trade openness and corruption controls not not only influence economic growth directly (Hye, Wizarat \& Lau, 2016; Musila \& Yiheyis, 2015), but it also influences the development of the stock market. The effects of corruption on the development of the stock market (Modugu \& Depere, 2020; Kim, Li \& Tarzia, 2018; Bolgorian, 2011) and the impacts of corruption on trade openness (Gil-Pareja, LlorcaVivero \& Martinez-Serrano, 2019; Thede \& Gustafson, 2012); as well as the influences of trade openness on the stock market have been reported in several studies in the 
past (Nikmanesh, 2016; Lim \& Kim, 2011). Thus, in order to lead to the economic growth, the control of corruption and the development of the stock market under open economic conditions are the top priorities for developing nations.

Many empirical studies have been performed in the past on the influence of corruption on economic development, but very few studies have been undertaken on the influence of corruption regulation on economic growth through the connection between corruption control and stock market or trade openness. This study will, therefore, solve the void left by the previous studies. This report would offer new scientific evidences and resolve the needs of administrators in developing countries. Since then, steps to improve the prevention of corruption have also been suggested to encourage the beneficial impact of stock market and trade openness, which leads to an increase in the economic development in developing countries in general and in Vietnam in particular.

\section{Theoretical Basis and Literature Review}

\subsection{Theoretical Basis}

The study focuses on the impact of corruption control on economic growth in the relationship with the stock market and trade openness in developing countries. Then, CobbDouglas production function reflects the factors of capital $(\mathrm{K})$, labor (L) and the efficiency of the aggregate factors (A) affecting the output value of an economy by the equation of the form: $\mathbf{Y}=\mathbf{A} \cdot \mathbf{K}^{\alpha} \cdot \mathbf{L}^{1-\alpha}$ that will be used to clarify the above relationship. Specifically, stock market, which provides capital to the economy, is a component of the capital factor $(\mathrm{K})$ of the growth model; trade openness facilitates businesses to expand consumption markets and technology investments (Bond, Jones \& Wang, 2005; Almeida \& Fernandes, 2008), thus contributing to the efficiency of the aggregate factors (A); finally, corruption control provides equitable and healthy business environment (Hooper, Sim \& Uppal, 2009; Talmaciu, 2014) and an incentive for investors (Svensson, 2003; Fisman \& Svensson, 2007), contributing to the efficiency of aggregate factors $\mathbf{A}$ of the growth model.

Besides, according to Barro's endogenous growth theory (1990), the role of governments will arise from public expenditures and the power of civil servants to exercise managerial roles. Corruption thus occurs when a number of civil servants abuse public power for personal benefits. Corruption damages the state budget through public investment activities (Olken \& Pande, 2012), leads to loss of people's trust in the management apparatus (Olken \& Baron, 2009; d'Agostino, Dunne \& Pieroni, 2016) and eliminate business motivation (Svensson, 2003; Fisman \& Svensson, 2007). As a result, government's implementation of corruption control contributes in minimizing corruption, strengthening people's trust, creating motivation to work and promoting economic growth.

\subsection{Literature Review}

A variety of studies have been performed on the effect of corruption control on economic growth through the variable corruption (Qu, Sylwester \& Wang, 2018; Mallik \& Saha, 2016; Pellegrini \& Reyer, 2004). The studies conducted on a group of countries with similar conditions show that corruption in countries with low political institutional quality is considered as a lubricant for the economy, helping the economy develop but corruption in countries with high institutional quality reduces economic growth (Aidt, Dutta \& Sena, 2008; Mallik \& Saha, 2016). In emerging countries, Poor regulation of corruption restricts economic growth, and corruption management is greater in wealthy countries, rendering the economy less affected by corruption (Cieślik \& Goczek, 2018). Some recent studies in developing countries where corruption is high, corruption significantly impedes firm revenue growth and labor productivity growth, limiting business innovation (Nguyen, 2020; Dutta \& Sobel, 2016).

There have been few studies which have focused on the effect of corruption control on economic growth in the relationship with other factors. In most countries, when the economy is open, the flow of investment capital has been facilitated to move from ineffective places to effective ones. A nation with high quality public government ensures that good corruption control will reduce transaction costs, reduce risks and increase the performance of stock market (Hooper, Sim \& Uppal, 2009; Ho \& Michaely, 1988). Increased market performance will bring more profits to investors (Hawawini, 1993), thus attracting more investors to participate in the capital market. According to Lombardo and Pagano (2000) capital flows will shift from a country with bad corruption control to a country with better corruption control to maximize investors' returns. A study by Nguyen, Nguyen and Schinckusb (2019) also shows that in a nation with a high degree of trade openness paired with good institution, its domestic market will draw more investors instead of targeting overseas investment markets. Thus, factor of corruption is one of the indicators reflecting institutions and impacts on the performance of stock market (Hooper, Sim \& Uppal, 2009; Kim, Li \& Tarzia, 2018).

Besides, with the opening of the economy, there is an increase in competition among countries and it will force countries to step up corruption control to attract investment (Levchenko, 2013; Torrez, 2002), which also implies that good corruption control will increase trade openness, contributing to increasing economic growth. Majeed (2014) finds that with the state agencies' privilege of issuing quality and origin certificates of goods for export increases the likelihood of corruption.

Review results of past empirical studies have shown that corruption control can affect economic growth as follows:

(1) Corruption control is a component of the aggregate factors in Cobb-Douglas growth model, which directly affects economic growth. 
(2) Corruption control affects economic growth through the mediating role of the relationship of corruption control and stock market. Then, corruption control affects the performance of capital use on stock market.

(3) Corruption control affects economic growth through the mediating role of the relationship of corruption control and trade openness. Then, corruption control affects the efficiency of trade openness.

Among the three ways of influencing corruption control on economic growth, the past studies focused the impacts in the way (1). According to the ways (2) and (3), there have been no studies conducted. The gap in the research that the author is interested in. Therefore, this study aims at two objectives:

(i) The impacts of corruption control on economic growth in developing countries in the relationship with stock market.

(ii) The impacts of corruption control on economic growth in developing countries in the relationship with trade openness.

\section{Study Method}

\subsection{Analytical Framework}

From theoretical basis and reviewed results, the analytical framework of the impacts of corruption control on economic growth in the relationship with stock market and trade openness is proposed as follows

\subsection{Study Model}

Following approach of Mankiw, Romer and Weil (1992), with the addition of human capital $(\mathrm{H})$, Cobb - Douglas production function is rewritten in terms of time $t$ to determine the output value of country $i$ in the form:

$$
Y_{i, t}=A_{i, t} \cdot K_{i, t}^{\propto} \cdot H_{i, t}^{\beta} \cdot L_{i, t}^{1-\infty-\beta} \quad \text { với } 0<\alpha, \beta<1
$$

Dividing both sides of (1) by $\mathrm{L}_{\mathrm{i}, \mathrm{t}}$, the result is:

$$
\begin{array}{r}
Y_{i, t} / L_{i, t}=A_{i, t}\left(\frac{K_{i, t}}{L_{i, t}}\right)^{\alpha} \cdot\left(\frac{H_{i, t}}{L_{i, t}}\right)^{\beta} \cdot\left(\frac{L_{i, t}}{L_{i, t}}\right)^{1-\alpha-\beta} \Leftrightarrow \\
y_{i, t}=A_{i, t} \cdot k_{i, t}^{\alpha} h_{i, t}^{\beta}
\end{array}
$$

With $\mathrm{y}_{\mathrm{it}}$ the output per capita; $\mathrm{k}_{\mathrm{it}}$ is the physical capital per capita; $h_{\text {it }}$ is human capital per capita, $\alpha$ and $\beta$ are the elasticities of physical capital or human capital.

Taking the two-sided decimal logarithm, the result is rewritten:

$$
\operatorname{Lg}\left(y_{i, t}\right)=\operatorname{Lg}\left(A_{i, t}\right)+\propto k_{i, t}+\beta h_{i, t}
$$

Stock market is also a channel to provide capital to the economy together with credit market, so this study uses variable stock market $(\mathrm{mc})$ and variable credit market $(\mathrm{dc})$ representing $\mathrm{k}_{\mathrm{it}}$ in model (3) like approach of Durusu-Ciftci, Ispir and Yetkiner (2017). According to Mankiw, Romer and Weil (1992), $A_{i t}$ reflects not only technological progress xxxxdbut also the differences in institutions, resources and business environment between countries over time. The institutional factor of a country is represented by indicator corruption control and governmental efficiency (go-eff) according to Cooray (2009); the business environment between countries over time is represented by indicator trade openness and the quality of laws according to Alcala and Ciccone's approach (2004). Thus, factors affecting overall efficiency $A_{i t}$ studied and used include variables such as technology (tech), trade openness (to), corruption control (cc), governmental efficiency (go-eff) and quality of laws (re-qua).

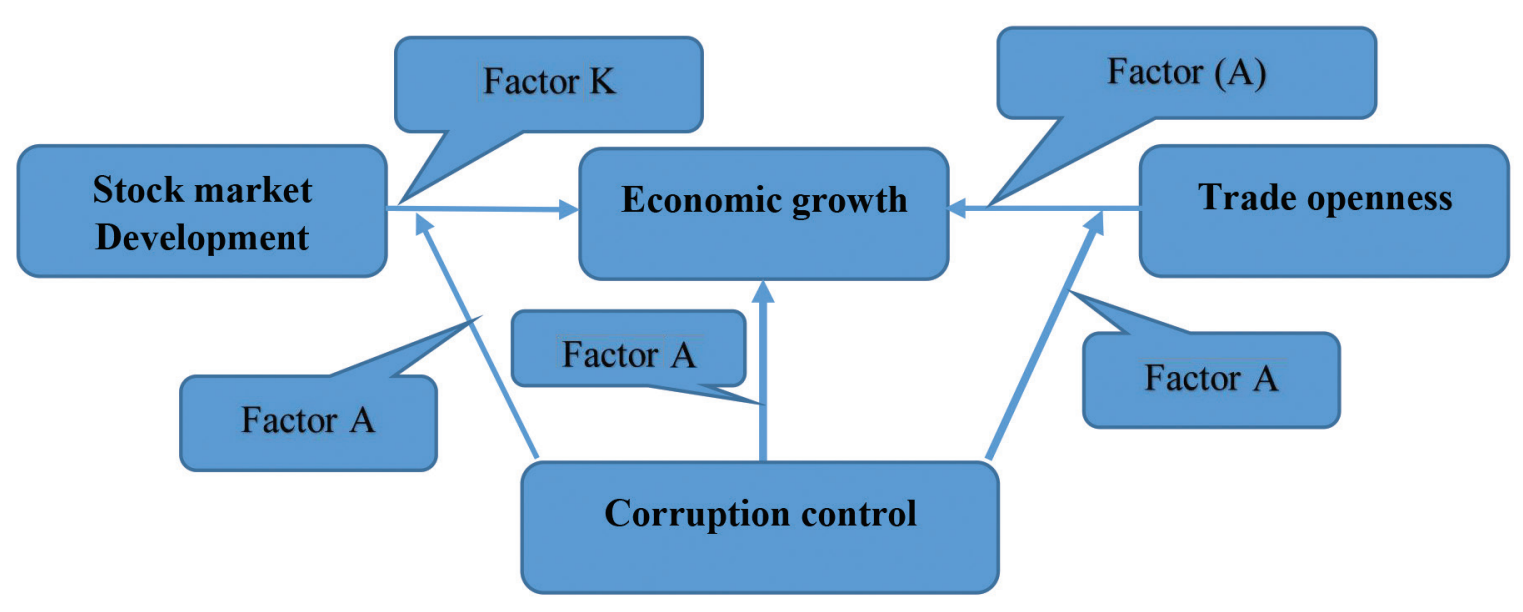


Their relationship is expressed as a performance function:

$$
A_{i, t}=A_{0}^{\delta 1 . t e c h+\delta 2 . t o+\delta 3 . c c+\delta 4 . g o_{-} e f f+\delta 5 . r e_{-} q u a+\varphi}
$$

Where $\mathrm{A}_{0}$ is the minimum performance level. Take the double-sided logarithm, the growth of $\mathrm{A}_{\mathrm{it}}$

$$
\begin{aligned}
& \operatorname{Lg}\left(A_{i, t}\right)=\left\{\delta_{1} \text { tech }{ }_{i, t}+\delta_{2} \text { to } o_{i, t}+\delta_{3} c c_{i, t}+\delta_{4} g o \_e f f\right. \\
& \left.+\delta_{5} r e \_q u a_{i, t}+\varphi_{i, t}\right\} \cdot \log \left(A_{0}\right) \\
& \text { Or } \operatorname{Lg}\left(A_{i, t}\right)=\sigma_{0}+\sigma_{1} \text { tech }{ }_{i, t}+\sigma_{2} t o_{i, t}+\sigma_{3} c c_{i, t}+\sigma_{4} g o \_ \text {eff } f_{i, t} \\
& +\sigma_{5} r e \_q u a_{i, t}+\theta_{i, t}
\end{aligned}
$$

According to Thanh and Canh (2020), the value of national output per capita in year $t$ is estimated by equation (6) from the combination (3) and (5):

$$
\begin{aligned}
\operatorname{Lg}\left(Y_{i, t}\right)= & \gamma_{0}+\gamma_{1} \operatorname{Lg}\left(m c_{i, t}\right)+\gamma_{2} \lg \left(d c_{i, t}\right)+\gamma_{3} \lg \left(h_{i, t}\right)+\gamma_{4}\left(\text { tech }_{i, t}\right) \\
& +\gamma_{5}\left(\text { to }_{i, t}\right)+\gamma_{6}\left(c c_{i, t}\right)+\gamma_{7}\left(g o \_ \text {eff } f_{i, t}\right)+\gamma_{8}(\text { re_qua } \\
& \left.+\varepsilon_{i, t}\right)
\end{aligned}
$$

In addition, on a long-term basis, Gross Domestic Product (GDP) per capita in one period determines savings, which determines investment over the next period, thus creating additional output for the next period. Therefore, the lag variable of dependent variable (Y) usually appears in the study model of economic growth (Thanh \& Canh, 2020; Fufa \& Kim, 2018). Then the dynamic table data regression model to estimate the impacts of stock market, trade openness and corruption control on economic growth is proposed:

$$
\begin{aligned}
\Delta L g\left(\gamma_{i, t}\right)= & \omega_{0}+\omega_{1} \lg \left(\gamma_{i, t-1}\right)+\omega_{2} \lg \left(m c_{i, t}\right)+\omega_{3} \lg \left(d c_{i, t}\right) \\
& +\omega_{4} \lg \left(h_{i, t}\right)+\omega_{5}\left(t e c h_{i, t}\right)+\omega_{6}\left(t o_{i, t}\right)+\omega_{7}\left(c c_{i, t}\right) \\
& +\omega_{8}(\text { go_eff })+\omega_{9}(\text { re_qua } \\
& \left.+\omega_{i, t}\right)+\omega_{i, t}+\theta_{i, t} \\
& +\mu_{i, t}
\end{aligned}
$$

With $\mathrm{Z}_{\mathrm{it}}$ as a control variable added according to the study's objectives.

From the theoretical model (7), the study adds inflation variable (inf) to reflect the macroeconomic environment factors affecting economic growth according to Arawatari, Hori and Mino (2018), Eggoh and Khan (2014).

$$
\begin{aligned}
\Delta L g\left(\gamma_{i, t}\right)= & \theta_{0}+\theta_{1} \lg \left(\gamma_{i, t-1}\right)+\theta_{2} \lg \left(m c_{i, t}\right)+\theta_{3} \lg \left(d c_{i, t}\right) \\
& +\theta_{4} \lg \left(h_{i, t}\right)+\theta_{5}(\text { tech } \\
& \left.+\theta_{i, t}\right)+\theta_{6}\left(\text { to }_{i, t}\right)+\theta_{7}\left(c c_{i, t}\right) \\
& +\theta_{8}\left(g o \_ \text {eff }\right)+\theta_{9, t}\left(\text { re_qua }_{i, t}\right)+\theta_{10} \text { inf } \\
& +\mu_{i, t}+\theta_{i, t}
\end{aligned}
$$

The thesis carried out two-step empirical research in order to assess the role of trade openness and corruption control on the impact of stock market development on economic growth. Firstly, the thesis examines the role of trade openness and corruption control in stock market development; then, evaluates the indirect effects of these two factors on economic growth through the stock market impact.

Following the approach of Baltagi, Demetriades and Law (2008) who examined the role of trade openness and institutional quality on financial development, this study examines the role of trade openness and the control of corruption in stock market development. A similar empirical model according to Baltagi, Demetriades and Law (2008):

$$
\begin{aligned}
\operatorname{Lg}\left(m c_{i, t}\right)= & \gamma_{0}+\gamma_{1} \operatorname{Lg}\left(m c_{i, t-1}\right)+\gamma_{2} \lg \left(y_{i, t}\right)+\gamma_{3} \lg \left(d c_{i, t}\right) \\
& +\gamma_{4} t o_{i, t}+\gamma_{5}\left(c c_{i, t}\right)+\theta_{i, t}
\end{aligned}
$$

In which, the stock market development variable (mc) plays the role of the dependent variable, similar to the financial development variable (FD); corruption control variables (cc) represent institutional quality variables (INS); Financial openness variable (FO) is explained as a variable of credit market size relative to GDP (dc) according to research by Baltagi, Demetriades and Law (2008). Since the control variable (cc) has a normal distribution in the range $[-2,5$ 2,5], the decimal logarithm is not taken; The commercial openness variable (to) does not take the decimal logarithm because the study wants to maintain the data type according to the experimental model (8).

The results of empirical research according to model (9) will be the basis to consider whether the role of trade openness or control of corruption exists in the development of the stock market. If this role exists, the thesis will continue to study the indirect effects on economic growth of trade openness or control of corruption through the impact on the stock market in line with the set goals. To solve the first objective, the study is added with an interaction variable between corruption control and stock market. Then, variable corruption control is used to measure the level of corruption control (cc-level), receiving only one of the 1 or 0 values representing good corruption control and vice versa.

$$
\begin{aligned}
& \Delta L g\left(y_{i, t}\right)=a_{0}+a_{1} \lg \left(y_{i, t-1}\right)+a_{2} \lg \left(m c_{i, t}\right)+a_{3} \lg \left(d c_{i, t}\right)+a_{4} \lg \left(h_{i, t}\right) \\
& +a_{5}\left(\text { tech }_{i, t}\right)+a_{6}\left(\text { to }_{i, t}\right)+a_{7}\left(\text { cc_level } l_{i, t}\right)+a_{8}\left(\text { go_eff }_{i, t}\right) \\
& +a_{9}\left(\text { re_qua } a_{i, t}\right)+a_{10} i n f_{i, t}+a_{11}\left(\text { cc_level }_{i, t}\right) \cdot \lg \left(m c_{i, t}\right) \\
& +\theta_{i, t}+\mu_{i, t}
\end{aligned}
$$

Similarly, it is needed to add an interaction variable between corruption control and trade openness to solve the second objective. Then, variable corruption control is used to measure the level of corruption control (cc-level), receiving only one of the values 1 or 0 .

$$
\begin{aligned}
& \Delta L g\left(y_{i, t}\right)=b_{0}+b_{1} \lg \left(y_{i, t-1}\right)+b_{2} \lg \left(m c_{i, t}\right)+b_{3} \lg \left(d c_{i, t}\right)+b_{4} \lg \left(h_{i, t}\right) \\
& +b_{5}\left(\text { tech }_{i, t}\right)+b_{6}\left(\text { to }_{i, t}\right)+b_{7}\left(\text { cc_level }_{i, t}\right)+b_{8}\left(\text { go_eff }_{i, t}\right) \\
& +b_{9}\left(\text { re_qua } a_{i, t}\right)+\bar{b}_{10} \text { inf }_{i, t}+\bar{b}_{11}\left(\text { cc_level }_{i, t}\right) \cdot\left(\text { to }{ }_{i, t}\right) \\
& +\theta_{i, t}+\mu_{i, t}
\end{aligned}
$$


Table 1: Explain variables and measures

\begin{tabular}{|c|c|c|}
\hline Sign & Mean - Measure & Source \\
\hline i & is the index of sampled countries & \\
\hline $\mathrm{t}$ & are indicators reflecting observation time & \\
\hline $\mathrm{y}_{\text {it }}$ & is the value of output per capita, reflecting economic growth & World Bank (WB) \\
\hline $\mathrm{mc}_{\mathrm{it}}$ & $\begin{array}{l}\text { is the amount of capital from the stock market per capita as determined by the ratio (\%) of } \\
\text { market capitalization to GDP }\end{array}$ & WB \\
\hline $\mathrm{dc}_{\text {it }}$ & $\begin{array}{l}\text { is the amount of capital from the credit market per capita as determined by the ratio (\%) of } \\
\text { credit capital to GDP }\end{array}$ & \\
\hline $\mathrm{h}_{\mathrm{it}}$ & $\begin{array}{l}\text { is a human capital variable, measured by the HDI human development index (HDI). HDI } \\
\text { index is determined from } 3 \text { components: average life expectancy, education index and } \\
\text { income index }\end{array}$ & $\begin{array}{l}\text { United Nations } \\
\text { Development } \\
\text { Program. }\end{array}$ \\
\hline tech $_{\text {it }}$ & $\begin{array}{l}\text { is a common technological element of the economy, and is used as information } \\
\text { technology that workers access to handle jobs. In the context of an open economy and } \\
\text { global flat knowledge, information technology can be measured by the amount of means } \\
\text { used to access and share information of workers (Farhadi, Ismail \& Fooladi, 2012) }\end{array}$ & WB \\
\hline to & is an trade openness measured by the ratio of import-export value to GDP & WB \\
\hline $\mathrm{CC}_{\text {it }}$ & $\begin{array}{l}\text { is a corruption control index provided by the WB with a standard distribution from [-2.5 } \\
2.5] \text {. The higher the level, the better the assertion of controlling corruption, the less } \\
\text { corrupt the country. }\end{array}$ & WB \\
\hline $\mathrm{cpi}_{\mathrm{i}, \mathrm{t}}$ & $\begin{array}{l}\text { is Corruption Perception Index (CPI), is the second scale of corruption, measuring the } \\
\text { level of corruption perceived which exists among officials, politicians, and civil servants, } \\
\text { provided by business people and analysts. }\end{array}$ & $\begin{array}{l}\text { Transparency } \\
\text { International (TI) }\end{array}$ \\
\hline go-eff $_{\text {it }}$ & $\begin{array}{l}\text { is effective government, reflecting the quality of public services as well as government } \\
\text { policy formulation and commitment, as measured by the World Bank in its annual set of } \\
\text { public governance indicators. }\end{array}$ & WB \\
\hline re-qua ${ }_{i t}$ & $\begin{array}{l}\text { is the quality of law, reflecting the formulation and implementation of policies to support } \\
\text { private sector development as measured by the WB in the set of public governance } \\
\text { indicators and published annually. }\end{array}$ & WB \\
\hline to-level & $\begin{array}{l}\text { is a qualitative variable measuring the degree of trade openness, which is given one } \\
\text { of two values } 1 \text { and } 0 \text {, corresponding to high trade openness (when trade openness > } \\
\text { average of the sample) and vice versa. }\end{array}$ & \\
\hline cc-level & $\begin{array}{l}\text { is a qualitative variable measuring the country's control of corruption, having one of two } \\
\text { values } 1 \text { and } 0 \text {, corresponding to the level of good control of corruption (when cc }>0 \text { ) and } \\
\text { vice versa. }\end{array}$ & \\
\hline cpi-level & $\begin{array}{l}\text { is also a qualitative variable, which measures the country's perceived level of corruption, } \\
\text { which is given one of two values } 1 \text { and } 0 \text {, corresponding to the perception of low } \\
\text { corruption, ie less corruption or good control corruption (when cpi > 5) and vice versa. }\end{array}$ & \\
\hline
\end{tabular}

\subsection{Data and Study Method}

The sample of developing countries with stock market according to IMF's classification is suitable for the study period (2002-2017). The study data is a table dataset of developing countries with active stock market for the period (2002-2017). The measurement data for the variables are extracted from the WB. In the dataset, there are 576 observations for complete variables such as GDP, effective government. Besides, there are also some variables insufficient 576 observations such as variables credit market and inflation. For variables insufficient observations, a country with less than 9 observations during the 16-year study period won't be selected. In addition, corruption measurement criteria include Corruption Perceptions Index (cpi) provided by Transparency International in addition to World Bank's corruption control. CPI is given a score of from 1 to 10 , with the higher score, the country is understood to be less corrupt and vice versa.

The study uses STATA 14 software to conduct correlation analysis among variables, build regression models and model tests. According to model (10) \& (11), there is a 
lag variable of the dependent variable, so an endogenous phenomenon is suspected to exist in the model. In addition, the data sample has a shorter study period $(\mathrm{T}=16)$ than the number of observations $(\mathrm{N}=36)$, so it is suitable for using S-GMM two-step (Blundell \& Bond, 1998) estimation model on dynamic table models. This technique can estimate the endogenous growth model more appropriately than the FEM method (Arellano \& Bond, 1991; Baltagi, 2005). In addition, endogenous variables often appear in the growth models, causing errors for OLS regression; the use of exogenous instrumental variables can help regressions overcome this problem (Barro, 1990; Acemoglu, Johnson \& Robinson, 2005). Compared with the static table based regression models such as OLS, FEM, REM, 2SLS, two-step difference S-GMM estimation method solves endogeneity and deals with the inefficiency due to heterogeneity to estimate appropriately and effectively (Windmeijer, 2005; Siddiqui \& Ahmed, 2013).

\section{Results and Discussion}

Firstly, the study considers the most general relationship between variables in the model by analyzing descriptive statistics, and correlation coefficients of variables. Next, the study will estimate the regression coefficient to determine the degree of impacts between the main independent variables of the study (to, mc, cc) on dependent variable $\mathrm{Y}$ of the study model $\left(\mathrm{d} \cdot \mathrm{y}_{\mathrm{it}}\right)$ according to (8). Next, the study examines the role of trade openness or corruption control to stock market development by model (9). After that, the study focuses specifically on each objective (i) and (ii) according to (10) and (11).

Descriptive statistical results shown in Table 2 show the number of observations, mean values, standard errors, minimum value and maximum value of the variables before calculating decimal logarithm. In developing countries, the mean value of GDP per capita is USD 7,017 per year; the mean value of variables cc or cpi shows a high degree of corruption (cpi $<5$ or $\mathrm{cc}<0$ ).

Table 2: Descriptive statistics of variables

\begin{tabular}{|l|c|c|c|c|c|}
\hline Variables & Obs & Means & Std. Dev & Min & Max \\
\hline y (USD) & 576 & $7,017.266$ & $7,501.193$ & 395.849 & $45,758.9$ \\
\hline mc (\%) & 501 & 51.228 & 48.915 & 3.856 & 215.292 \\
\hline dc (\%) & 559 & 73.4387 & 43.3953 & -10.1518 & 1.5923 \\
\hline cc & 576 & -0.2462 & 0.5660 & -1.4965 & 7.3 \\
\hline cpi & 576 & 4.2689 & 1.7729 & 0.2072 & 2.1037 \\
\hline to & 570 & 0.8023 & 0.3986 & 0.45 & 0.0134 \\
\hline h & 572 & 0.7018 & 0.0924 & -1.2146 & 3.6348 \\
\hline tech & 572 & 1.3337 & 0.7379 & -1.7201 & 1.5099 \\
\hline go-eff & 576 & 0.0105 & 0.5070 & -3.7492 & 4.5385 \\
\hline re-qua & 576 & 0.0287 & 0.5752 & 5.0729 & \\
\hline inf (\%) & 562 & 5.8128 & & & 4 \\
\hline
\end{tabular}

Table 3: Correlation coefficient between variables

\begin{tabular}{|c|c|c|c|c|c|c|c|c|c|}
\hline & $\operatorname{Lg}(y)$ & Lg(mc) & Lg(dc) & Lg(h) & tech & cc & to & inf & go-eff \\
\hline $\mathrm{Lg}(\mathrm{mc})$ & $0.242^{* * *}$ & & & & & & & & \\
\hline $\operatorname{Lg}(\mathrm{dc})$ & $0.186^{* * *}$ & $0.480^{* * *}$ & & & & & & & \\
\hline $\operatorname{Lg}(\mathrm{h})$ & $0.161^{* * *}$ & -0.074 & $0.088^{*}$ & & & & & & \\
\hline tech & $0.548^{\star * *}$ & $0.216^{* * *}$ & $0.347^{* * *}$ & $0.144^{* * *}$ & & & & & \\
\hline $\mathrm{cc}$ & $0.586^{* * *}$ & $0.394^{* * *}$ & $0.283^{* * *}$ & 0.011 & $0.314^{\star \star \star}$ & & & & \\
\hline to & $0.319^{* * *}$ & $0.146^{* * *}$ & $0.272^{* * *}$ & 0.027 & $0.284^{* * *}$ & $0.413^{* * *}$ & & & \\
\hline $\inf$ & $-0.332^{* * *}$ & $-0.430^{* * *}$ & $-0.345^{\star * *}$ & $-0.102^{* *}$ & $-0.199^{* * *}$ & $-0.399^{* * *}$ & $-0.353^{* * *}$ & & \\
\hline go-eff & $0.609^{* * *}$ & $0.535^{* * *}$ & $0.457^{* * *}$ & 0.055 & $0.317^{* * *}$ & $0.803^{* * *}$ & $-0.519^{* * *}$ & $-0.520^{* * *}$ & \\
\hline re-qua & $0.689^{* * *}$ & $0.450^{\star \star *}$ & $0.248^{* * *}$ & 0.074 & $0.279^{* * *}$ & $0.789^{* \star *}$ & $-0.457^{\star \star *}$ & $-0.486^{* * *}$ & $0.810^{\star * \star}$ \\
\hline
\end{tabular}


The results in Table 3 show that the main variables such as lg-mc, lg-dc, lg-h, cc, tech, to have correlation coefficients lower than 0.59 , ie the correlation level is weak and average. In addition, the variables reflecting the institution and business environment taken from the public governance dataset, such as cc, go-eff, and re-qua, are relatively highly correlated with $\lg (\mathrm{y})$ and are highly correlated with each other at the same time. This shows that most of the variables reflect institutional, business environment factors are closely related to the economic growth of the countries.

Table 4: Impacts of corruption control, stock market and trade openness on economic growth

\begin{tabular}{|l|c|c|}
\hline $\begin{array}{l}\text { Dependent variable } \\
\text { d.Igy }\end{array}$ & $\begin{array}{c}\text { M1 } \\
\text { (8) follow cc }\end{array}$ & $\begin{array}{c}\text { M2 } \\
\text { (8) follow cpi }\end{array}$ \\
\hline L1.Lg(y) & $-0.111^{* * *}$ & $-0.108^{* * *}$ \\
& $(0.015)$ & $(0.012)$ \\
\hline Lg(mc) & $-0.056^{* *}$ & $-0.053^{* * *}$ \\
& $(0.015)$ & $(0.014)$ \\
\hline Lg(dc) & $0.050^{* * *}$ & $0.037^{* * *}$ \\
& $(0.009)$ & $(0.006)$ \\
\hline to & $0.044^{* * *}$ & $0.037^{* * *}$ \\
& $(0.014)$ & $(0.008)$ \\
\hline cc & $0.059^{* * *}$ & \\
& $(0.021)$ & \\
\hline cpi & & $0.008^{* *}$ \\
\hline Lg(h) & & $(0.004)$ \\
\hline tech & 0.014 & 0.006 \\
& $(0.075)$ & $(0.063)$ \\
\hline go-eff & -0.001 & 0.001 \\
& $(0.006)$ & $(0.005)$ \\
\hline re-qua & -0.018 & -0.012 \\
& $(0.024)$ & $(0.019)$ \\
\hline inf & -0.001 & 0.010 \\
& $(0.013)$ & $(0.011)$ \\
\hline Const & $0.005^{* * *}$ & $0.005^{* * *}$ \\
& $(0.001)$ & $(0.001)$ \\
\hline Number of instruments/ & $0.404^{* * *}$ & $0.361^{* * *}$ \\
Number of groups & $(0.059)$ & $(0.075)$ \\
\hline Arellano-Bond test AR(1) & $34 / 36$ & $34 / 36$ \\
\hline Arellano-Bond test AR(2) & 0.024 & 0.025 \\
\hline Hansen test 1 & 0.267 & 0.224 \\
\hline * significant at 10 percent level & 0.172 \\
$* * *$ significant at 5 percent level & & \\
$* * *$ significant at 1 percent level & & \\
\hline & & \\
\hline
\end{tabular}

The regression results determining the impacts of corruption control, stock market and trade openness on economic growth according to (8) are reflected in table 4 in two scales of corruption. Column M1 presents the results based on variable cc, column M2 corresponds to cpi results. The main variables of the study are highlighted in terms of results. Regression coefficients of the main variables are statistically significant with $\mathrm{p}$-value $<5 \%$. The test results of S-GMM method show no quadratic sequence autocorrelation (AR (2) with p-value $>$ $10 \%)$ in the first-order (AR(1) with p-value $<5 \%$ ) correlation constraint in 2 results; the number of instrumental variables is less than the number of groups; Hansen test of excessive constraints (with p-value $>10 \%$ ) shows no correlation between instrumental variable and errors. Thus, the used instrumental variables are reasonable. The results also confirm that the stock market has a minimal effect on the economic growth, while credit market has a positive impact on the economic growth, reflecting the trade-off in the role of providing capital to the economy similar to the approach of Durusu-Ciftci, Ispir and Yetkiner (2017). The one-period lag variable of variable economic growth has a negative regression coefficient, confirming the convergence sign of economic growth in future (Tondl, 2001). Trade openness promotes economic growth (similar to Musila \& Yiheyis, 2015; Shahbaz, 2012) and the degree of cc or cpi all has a significant impact on the economic growth (similar to Cieślik \& Goczek, 2018; Chang \& Hao, 2017; Mallik \& Saha, 2016). This indicates that, when the corruption controls are inefficient (cc or cpi decreases), economic growth declines, and when corruption controls are stronger or corruption is smaller (cc or cpi increases), then the economic growth improves.

To assess the role of trade openness or corruption control on economic growth through its effects on the stock market, the study will consider the role of trade openness or corruption control to development of the stock market according to model (9) according to the approach of Baltagi, Demetriades and Law (2008) with the dependent variable being the development of the stock market $(\mathrm{Lg}(\mathrm{mc}))$. The results estimate the regression coefficients of the independent variables of trade openness (to) and corruption control (cc) according to the empirical model (9) it is examined whether the effect of trade openness or corruption control has an effect on the stock market development or not. Table 5 presents the regression results (9) according to S-GMM estimation method.

Estimated results show that all the independent variables are statistically significant at the $1 \%$ level. Tests of the S-GMM method such as the quadratic correlation in the constraint with the first correlation are satisfactory, the number of instrumental variables is smaller than the number of groups, Hansen's test on over-constraint shows that there is no self-correlation phenomenon between instrument variables and errors. Thus, the instrumental variables used are reasonable and the estimated results are reliable. 
Table 5: Regression results

\begin{tabular}{|l|c|c|c|}
\hline Dependent variable $\mathbf{L g}(\mathbf{m c})$ & Coefficient & Standard deviation & P-value \\
\hline $\mathrm{L} 1 . \mathrm{Lg}(\mathrm{mc})$ & 0.828 & 0.017 & 0.000 \\
\hline $\mathrm{Lg}(\mathrm{y})$ & 0.051 & 0.016 & 0.002 \\
\hline $\mathrm{Lg}(\mathrm{dc})$ & -0.113 & 0.024 & 0.000 \\
\hline to & -0.158 & 0.031 & 0.000 \\
\hline $\mathrm{cc}$ & -0.101 & 0.037 & 0.006 \\
\hline go-eff & 0.193 & 0.030 & 0.000 \\
\hline Const & 0.412 & 0.088 & 0.000 \\
\hline Number of instruments/Number of groups & & $30 / 36$ & \\
\hline Arellano-Bond test AR(1) & \multicolumn{3}{|l}{} \\
\hline Arellano-Bond test AR(2) & \multicolumn{3}{|l|}{0.015} \\
\hline Hansen test 1 & \multicolumn{3}{|l}{0.583} \\
\hline
\end{tabular}

Both the regression coefficients of the trade openness variable (to) and the corruption control variable (cc) have negative signs and are statistically significant, demonstrating the existence of the role of trade openness on controlling corruption. They affect the development of the stock market in the opposite direction. The relationship between the credit market $(\lg (\mathrm{dc}))$ and the stock market $(\lg (\mathrm{mc}))$ is still consistent with the law of trade-off, that is, an increase in one market will make the other market decrease, similar to research results of Durusu-Ciftci, Ispir and Yetkiner (2017). With a sample of developing countries in the period (2002-2017), it shows that trade openness has a negative impact on stock market development, similar to the research findings of Lim and Kim (2011); Nikmanesh (2016) in Thailand. In addition, the control of corruption also has a negative impact on the development of the stock market, implying that the control of corruption in developing countries in the period (2002-2017) tends to decline. That is, the increase in corruption creates more favorable conditions for stock market development. Thus, the role of trade openness and corruption control has its limited impact on the development of the stock market. This is the basis for the study to consider the indirect effects of trade openness and corruption control on economic growth through the stock market according to two proposed objectives.

The regression results of model (10) for the first objective of this study are also carried out through two scales of corruption, cc and cpi presented in columns M3 and M4 of table 6. Variable trade openness has a positive impact on the economic growth; One-period lag variables of economic growth and stock market have a limited impact on economic growth. The variables representing the degree of corruption control or cpi have a positive impact on the economic growth, indicating that the better the corruption control is, the more economic growth happens. Whichever scale is used for corruption, the impact direction of these variables on economic growth is unchanged and the regression coefficients are also statistically significant.
The impact of corruption control on economic growth can be considered through the relationship with stock market based on the regression coefficient of the interaction variable between corruption control and stock market according to the results (10) from columns M3 and M4. This interaction variable with a negative regression coefficient and statistical significance indicates that there is an interaction impact between corruption control and stock market on economic growth. The regression coefficients of interaction variables with negative signs show that variable stock market has an opposite impact on variable corruption control, ie when variable stock market increases, variable corruption control decreases, meaning that the corruption increases. Corruption not only affects the performance of stock market (Hooper, Sim \& Uppal, 2009; Bolgorian, 2011) but also the performance of the growth model by reducing the motivation and performance of all the resources in the economy (Duncan, 2014; Talmaciu, 2014). Therefore, the result of this interaction restricts economic growth in the impact direction of corruption control on the economic growth. Thus, corruption control shows the role of dominating the impacts of stock market on economic growth, the first objective of this study is clarified.

The regression results (11) for the study's second objective has also been presented in table 6 which are also performed through two scales of corruption. The sign results of the main variables considered by the study are homogeneous and statistically significant. The interaction variable between corruption control and trade openness is the factor of evaluating the second objective of the study with statistical significance and negative regression coefficient. This shows that the impacts of corruption control on economic growth through the relationship with trade openness exist in the opposite direction. When trade openness increases, corruption control decreases, thus reducing economic growth in the impact direction of corruption control. Thus, corruption control overwhelms the impacts of trade openness on economic growth, the second objective is clarified. 
Table 6: The estimated regression results of models (10) and models (11)

\begin{tabular}{|c|c|c|c|c|}
\hline $\begin{array}{l}\text { Dependent variable } \\
\text { d.lgy }\end{array}$ & $\begin{array}{c}\text { M3 } \\
\text { (10) follow cc }\end{array}$ & $\begin{array}{c}\text { M4 } \\
\text { (10) follow cpi }\end{array}$ & $\begin{array}{c}\text { M5 } \\
\text { (11) follow cc }\end{array}$ & $\begin{array}{c}\text { M6 } \\
\text { (11) follow cpi }\end{array}$ \\
\hline L1.Lg(y) & $\begin{array}{c}-0.062^{* * *} \\
(0.013) \\
\end{array}$ & $\begin{array}{c}-0.096^{\star * *} \\
(0.020)\end{array}$ & $\begin{array}{c}-0.126^{* * *} \\
(0.016)\end{array}$ & $\begin{array}{c}-0.091^{* * *} \\
(0.020)\end{array}$ \\
\hline $\operatorname{Lg}(m c)$ & $\begin{array}{c}-0.040^{* * *} \\
(0.006)\end{array}$ & $\begin{array}{c}-0.031^{* *} \\
(0.011)\end{array}$ & $\begin{array}{c}-0.074^{* * *} \\
(0.017)\end{array}$ & $\begin{array}{c}-0.069 * * \\
(0.027)\end{array}$ \\
\hline $\operatorname{Lg}(d c)$ & $\begin{array}{l}0.034^{* * *} \\
(0.006)\end{array}$ & $\begin{array}{l}0.026^{* *} \\
(0.010)\end{array}$ & $\begin{array}{l}0.051^{* * *} \\
(0.007)\end{array}$ & $\begin{array}{l}0.080 * * * \\
(0.011)\end{array}$ \\
\hline to & $\begin{array}{l}0.027^{* * *} \\
(0.006)\end{array}$ & $\begin{array}{l}0.037^{* * *} \\
(0.011)\end{array}$ & $\begin{array}{l}0.037^{* * *} \\
(0.011)\end{array}$ & $\begin{array}{l}0.105^{* * *} \\
(0.025)\end{array}$ \\
\hline cc-level & $\begin{array}{l}0.018^{* *} \\
(0.009) \\
\end{array}$ & & $\begin{array}{c}0.042^{* * *} \\
(0.011)\end{array}$ & \\
\hline cc-level* $\operatorname{Lg}(\mathrm{mc})$ & $\begin{array}{l}-0.014^{*} \\
(0.008)\end{array}$ & & $\begin{array}{c}-0.038^{* * *} \\
(0.011)\end{array}$ & \\
\hline cpi-level & & $\begin{array}{l}0.026 * * * \\
(0.008)\end{array}$ & & $\begin{array}{l}0.155^{* * *} \\
(0.023)\end{array}$ \\
\hline cpi-level* $\lg (\mathrm{mc})$ & & $\begin{array}{c}-0.015^{\star \star *} \\
(0.004)\end{array}$ & & $\begin{array}{c}-0.213^{* * *} \\
(0.031)\end{array}$ \\
\hline $\operatorname{Lg}(h)$ & $\begin{array}{l}-0.028 \\
(0.046)\end{array}$ & $\begin{array}{c}0.002 \\
(0.057) \\
\end{array}$ & $\begin{array}{c}0.048 \\
(0.078)\end{array}$ & $\begin{array}{c}0.064 \\
(0.080) \\
\end{array}$ \\
\hline tech & $\begin{array}{c}-0.024^{* * *} \\
(0.004)\end{array}$ & $\begin{array}{c}-0.019^{* * *} \\
(0.007)\end{array}$ & $\begin{array}{l}0.0003 \\
(0.001) \\
\end{array}$ & $\begin{array}{l}-0.017^{* *} \\
(0.006)\end{array}$ \\
\hline go-eff & $\begin{array}{l}-0.009 \\
(0.013) \\
\end{array}$ & $\begin{array}{c}0.007 \\
(0.014) \\
\end{array}$ & $\begin{array}{l}0.054^{* * *} \\
(0.019)\end{array}$ & $\begin{array}{c}0.045 \\
(0.033) \\
\end{array}$ \\
\hline re-qua & $\begin{array}{c}0.048 \\
(0.008)\end{array}$ & $\begin{array}{l}0.049^{* * *} \\
(0.012)\end{array}$ & $\begin{array}{c}0.002 \\
(0.013)\end{array}$ & $\begin{array}{l}-0.036^{*} \\
(0.019)\end{array}$ \\
\hline $\inf$ & $\begin{array}{l}0.001^{* * *} \\
(0.0004)\end{array}$ & $\begin{array}{l}0.005^{* * *} \\
(0.001)\end{array}$ & $\begin{array}{l}0.006^{* * *} \\
(0.001)\end{array}$ & $\begin{array}{l}0.005^{* * *} \\
(0.001)\end{array}$ \\
\hline Const & $\begin{array}{l}0.274^{* * *} \\
(0.008)\end{array}$ & $\begin{array}{c}0.361 \\
(0.079) \\
\end{array}$ & $\begin{array}{l}0.484^{* * *} \\
(0.082)\end{array}$ & $\begin{array}{l}0.276^{* * *} \\
(0.089)\end{array}$ \\
\hline $\begin{array}{l}\text { Number of instruments/Number } \\
\text { of groups }\end{array}$ & $36 / 36$ & $32 / 36$ & $35 / 36$ & $35 / 36$ \\
\hline Arellano-Bond test $\mathrm{AR}(1)$ & 0.013 & 0.029 & 0.014 & 0.007 \\
\hline Arellano-Bond test $\mathrm{AR}(2)$ & 0.767 & 0.410 & 0.177 & 0.974 \\
\hline Hansen test 1 & 0.162 & 0.172 & 0.252 & 0.430 \\
\hline
\end{tabular}

\section{Conclusions and Implications}

The study discovers the dominant impact of corruption control in the relationship with stock market on economic growth. At the same time, the study also confirms the overwhelming impact of corruption control in the relationship between trade openness and economic growth in the developing countries. In addition, the study demonstrates that inefficient stock market of developing countries does not promote economic growth. Meanwhile, the longstanding credit market has a positive impact on the economic growth. In the context of open global economy, countries have constantly increased investment and production. Under strain to provide capital for the economy, both stock market and credit market must expand their sizes. Then, the issue of corruption control in developing countries does not timely increase with the rise of stock market and trade openness. Hence, the interaction of corruption control on 
the relationship with stock market or trade openness hinders economic growth in the impact direction of corruption control.

With the dominant role of variable corruption control on the relationship with stock market and economic growth, policy makers must build a system of appropriate and sustainable solutions to improve the efficiency of corruption control on stock market. Subsequently, solutions of corruption control must be drastically implemented at securities companies that conduct IPOs to state-owned enterprises and large groups to increase the efficiency of stock market in order to promote positive impacts of corruption control on economic relations for increasing economic growth in the future. One of the factors that create stock market and credit market is the belief in laws of investors in particular and social communities in general. Therefore, corruption control, which strengthens the institutional quality in the direction of information transparency and illegal behavior control in the financial market, will contribute in improving the society's belief in financial services. From there, the development of stock market will sustainably promote the economic growth.

In developing countries, corruption control, which is widespread but inefficient, limits economic growth. Corruption becomes common in customs agencies in lowincome countries. Therefore, the government of these countries must strengthen corruption control at customs gates and activities related to import and export of goods. At the same time, the government must have resources to support businesses to report the abuses of customs officials, minimize the violations of civil servants in obstructing the businesses' import and export activities. Raising awareness and responsibility of businesses involved in import and export activities is also an effective anti-corruption tool. The government should introduce appropriate reward and punishment polices in the fight against corruption in the import and export of goods, which will contribute in promoting businesses' rights and partially help the government in their effort to minimize corruption. For example, if a business provides evidences that customs officials abuse or obstruct the import and export of the business or take bribes, the business will be rewarded with cash at a satisfactory level. Promoting the proactive role of businesses is also an effective supervision channel to increase corruption control. However, if a business bribes customs officers to import prohibited goods, such business and customs officers shall also be subject to severe penalties to minimize damages to the national economy.

\section{References}

Acemoglu, D., \& Robinson, J. (2010). The role of institutions in growth and development. Review of Economics and Institutions, 1(2), 1-33. http://dx.doi.org/10.5202/rei.v1i2.14
Acemoglu, D., Johnson, S., \& Robinson, J.A. (2005). Institutions as a Fundamental Cause of Longterm Growth. In: P. Aghion \& S. N. Durlauf (Eds.), Handbook of Economic Growth (pp. 385-472). Elsevier. https://doi.org/10.3386/w10481

Aidt, T., Dutta, J., \& Sena, V. (2008). Governance regimes, corruption and growth: Theory and evidence. Journal of Comparative Economics, 36(2), 195-220. https://doi. org/10.1016/j.jce.2007.11.004

Alcala, F., \& Ciccone, A. (2004). Trade and productivity. Quarterly Journal of Economics, 119, 613-646. https://doi. org/10.1162/0033553041382139

Almeida, R., \& Fernandes, A.M. (2008). Openness and Technological Innovations in Developing Countries: Evidence from Firm-level Surveys. The Journal of Development Studies, 44(5), 701-727. https://doi.org/10.1080/00220380802009217

Arawatari, R., Hori, T., \& Mino, K. (2018) On the Nonlinear Relationship between Inflation and Growth: A theoretical exposition. Journal of Monetary Economics, 94, 79-93. https:// doi.org/10.1016/j.jmoneco.2017.12.001

Arellano, M., \& Bond, S. (1991). Some tests of specification for panel data: Monte Carlo evidence and an application to employment equations. Review of Economic Studies, 58(2), 277-297. https://doi.org/10.2307/2297968

Baltagi, B., Demetriades, P., \& Law, S. H. (2008). Financial development, openness and institutions: Evidence from panel data. Journal of Development Economics, 89(2), 285-296. https://doi.org/10.2139/ssrn.1808903

Baltagi, B. H. (2005). Econometric Analysis of Panel Data. West Sussex, England: John Wiley \& Sons Ltd.

Barro, R.J. (1990). Government Spending in a Simple Model of Endogenous Growth. Journal of Political Economy, 98(5), S103-126. https://doi.org/10.3386/w2588

Blundell, R., \& Bond, S. (1998). Initial conditions and moment restrictions in dynamic panel data models. Journal of Econometrics, 87(1), 115-143. https://doi.org/10.1920/ WP.IFS.1995.9517

Bolgorian, M. (2011). Corruption and stock market development: A quantitative approach. Physica A Statistical Mechanics and its Applications, 390(23-24), 4514-4521. https://doi. org/10.3846/btp.2016.555

Bond, E. W., Jones, R. W., \& Wang, P. (2005). Economic Takeoffs in a Dynamic Process of Globalization. Review of International Economics, 13(1), 1-19. https://doi.org/10.1111/j.1467-9396. 2005.00489.x

Chan,g C., \& Hao, Y. (2017). Environmental Performance, Corruption and Economic Growth: Global Evidence Using a New Data Set. Applied Economics, 49(5), 498-514. https://doi. org/10.1080/00036846.2016.1200186

Cieślik, A., \& Goczek, L. (2018). Control of Corruption, International Investment, and Economic Growth - Evidence from Panel Data. World Development, 103, 323-335. https:// doi.org/10.1016/j.worlddev.2017.10.028 
Cooray, A. (2009). Government Expenditure, Governance and Economic Growth. Comparative Economic Studies, 51, 401-418. https://doi.org/10.1057/ces.2009.7

d'Agostino, G., Dunne, J. P., \& Pieroni, L. (2016). Government Spending, Corruption and Economic Growth. World Development, $\quad 84, \quad$ 190-205. https://doi.org/10.1016/j. worlddev.2016.03.011

Duncan, R. (2014). Institutional quality, the cyclicality of monetary policy and macroeconomic volatility. Journal of Macroeconomics, 39, PartA, 113-155. https://doi.org/10.1016/j. jmacro.2013.11.004

Durusu-Ciftci, D., Ispir, M.S., \& Yetkiner, H., (2017). Financial Development and Economic Growth: Some Theory and More Evidence. Journal of Policy Modeling, 39(2), 209-306. https:// doi.org/10.1016/j.jpolmod.2016.08.001

Dutta, N., \& Sobel, R. (2016). Does corruption ever help entrepreneurship? Small Business Economics, 47(1), 179-199. https://doi.org/10/ggjpc8

Eggoh, J., \& Khan, M. (2014). On the nonlinear relationship between inflation and economic growth. Research in Economics, 68(2), 133-143. https://doi.org/10.1016/j.rie.2014.01.001

Farhadi, M., Ismail, R., \& Fooladi, M. (2012). Information and Communication Technology Use and Economic Growth. Plos One, 7(11), 1-7. https://doi.org/10.1371/journal.pone.0048903

Fisman, R., \& Svensson, J. (2007). Are Corruption and Taxation Really Harmful to Growth? Firm Level Evidence. Journal of Development Economics, 83(1), 63-75. https://doi. org/10.1016/j.jdeveco.2005.09.009

Fufa, J., \& Kim, J. (2018). Stock Market, Banks, and Economic Growth: Evidence from more Homogeneous Panels. Research in International Business and Finance, 44, 504-517. https:// doi.org/10.1016/j.ribaf.2017.07.120

Gil-Pareja, S., Llorca-Vivero, R., \& Martinez-Serrano, J. A. (2019). Corruption and international trade: A comprehensive analysis with gravity. Applied Economic Analysis, 27(79), 3-20. https:// doi.org/10.1108/AEA-06-2019-0003

Hawawini, G. (1993). MarketEfficiency and Equity Pricing: International Evidence and Implication for Global Investing. International Finance, Contemporary Issues. London and New York.

Ho, T. S., \& Michaely, R. (1988). Information Quality and Market Efficiency. Journal of Financial and Quantitative Analysis, 23, 53-70. https://doi.org/10.2307/2331024

Hooper, V., Sim, A. B., \& Uppal, A. (2009). Governance and stock market performance. Economic systems, 32(2), 93-116. https:// doi.org/10.1016/j.ecosys.2009.03.001

Hye, Q. M. A., Wizarat, S., \& Lau, W. Y. (2016). The impact of Trade Openness on Economic Growth in China: An Empirical Analysis. The Journal of Asian Finance, Economics and Business, 3(3), 27 - 37. https://doi.org/10.13106/jafeb.206. vol3.no3.27

Kim, D.S., Li, Y., \& Tarzia, D. (2018). Value of Corruption in China: Evidence from anti-corruption Investigation.
Economics Letters, 164, 112-116. https://doi.org/10.1016/j. econlet.2018.01.021

Lim, K. P., \& Kim, J. H. (2011). Trade openness and the informational efficiency of emerging stock markets. Economic Modelling, 28(5), 2228-2238. https://doi.org/10.1016/j. econmod.2011.06.004

Levchenko A (2013). International Trade and Institutional Change. Journal of Law, Economics and Organization 29: 1145 - 1181. https://doi.org/10.1093/jleo/ews008

Lombardo, D., \& Pagano, M. (2000). Legal Determinants of the Return on Equity. CSEF Working Paper 24, Naples. http:// dx.doi.org/10.2139/ssrn.209310

Majeed, M. T. (2014). Corruption and Trade. Journal of Economic Integration, 29(4), 759-782. https://doi.org/10.11130/ jei.2014.29.4.759

Mallik, G., \& Saha, S. (2016). Corruption and growth: A complex relationship. International Journal of Development, 15(2), 113-129. https://doi.org/10.1108/IJDI-01-2016-0001

Mankiw, N. G., Romer, D., \& Weil, D. (1992). A Contribution to the Empirics of Economic Growth. Quarterly Journal of Economics, CVII, 407-438. https://doi.org/10.3386/w3541

Modugu, K. P., \& Depere, J. (2020). Country-level Governance Quality and Stock Market Performance of GCC Countries. Journal of Asian Finance, Economics and Business, 7(8), 185-195. https://doi.org/10.13106/jafeb.2020.vol7.no8.185

Musila, J. W., \& Yiheyis, Z. (2015). The impact of trade openness on growth: The case of Kenya. Journal of Policy Modeling, 37(2), 342-354. https://doi.org/10.1016/j.jpolmod.2014.12.001

Nikmanesh, L. (2016). Trade openness and stock market volatility the ASEAN - 5 countries: New evidence using SUR. Investment Analysts Journal, 45(3), 194-211. https://doi.org/10.1080/1029 3523.2016.1172806

Nguyen, C. P., Nguyen, T. V. H., \& Schinckusb, C. (2019). Institutions, economic openness and stock return comovements: An empirical investigation in emerging markets. Finance Research Letters, 28, 137-147. https://doi. org/10.1016/j.frl.2018.04.010

Nguyen, T. N. (2020). Does Bribery Sand the Wheels? New Evidence from Small and Medium Firm in Vietnam. Journal of Asian Finance, Economics and Business, 7(4), 309 - 316. https://doi.org/10.13106/jafeb.2020.vol7.no4.309

Olken, B., \& Barron, P. (2009). The Simple Economics of Extortion: Evidence from Trucking in Aceh. Journal of Political Economy, 117(3), 417-452. https://doi.org/10.1086/599707

Olken, B. A., \& Pande, R. (2012). Corruption in developing countries. Annual Review of Economics, 4(1), 479-509. https:// doi.org/10.1146/annurev-economics-080511-110917

Pellegrini, L., \& Reyer, G. (2004). Corruption's effect on growth and its transmission channels. Kyklos, 57(3), 429-456. https:// doi.org/10.1111/j.0023-5962.2004.00261.x

Qu, G., Sylwester, K., \& Wang, F. (2018). Anti-corruption and growth: Evidence from China. European Journal of 
Political Economy, 55, 373-390. https://doi.org/10.1016/j. ejpoleco.2018.02.003

Shahbaz, M. (2012). Does trade openness affect long run growth? Cointegration, causality and forecast error variance decomposition tests for Pakistan. Economic Modelling, 29(6), 2325-2339. https://doi.org/10.1016/j.econmod.2012.07.015

Siddiqui, D. A., \& Ahmed, Q. M. (2013). The effect of institutions on economic growth: A global analysis based on GMM dynamic panel estimation. Structural Change and Economic Dynamics, 24(1), 18-33. https://doi.org/10.1016/j.strueco.2012.12.001

Spence, M. (2011). The next convergence. Washington, DC: Picador.

Talmaciu, M. (2014). Study on the Relationships between Institutions, Governance and Leadership and Regional Development Policy in Romania. Procedia Economics and Finance, 15, 1281-1288. https://doi.org/10.1016/S22125671(14)00589-9

Svensson, J. (2003). Who must pay bribes and how much? Evidence from a cross section of Firms. The Quarterly Journal of Economics, 118(1), 207 - 230. https://doi. org/10.1162/00335530360535180

Svensson, J. (2005). Eight questions about Corruption. Journal of Economic Perspectives, 19(5), 19-42. https://doi. org/10.1257/089533005774357860
Thanh, S. D., \& Canh, N. P. (2020). Fiscal decentralization and economic growth of Vietnammese provinces: The role of local public governance. Annals of Public and Cooperative Economics, 91(1), 119-149. https://doi.org/10.1111/apce.12255

Thede, S., \& Gustafson, N. A (2012). The multifaceted impact of corruption on international trade. The World Economy, 35(5), 651 - 666. https://doi.org/10.1111/j.1467-9701.2012.01436.x

Tondl, G. (2001). Convergence after divergence? Regional growth in Europe. New York, NY: Springer. https://doi. org/10.1007/978-3-7091-6219-4

Torrez, J. (2002). The Effect of Openness on Corruption. Journal of International Trade and Economic Development 11(4), 387-403. https://doi.org/10.1080/0963819022000014267

Treisman, D. (2000). The causes of corruption: A cross-national study. Journal of Public Economics, 76, 399-457. https://doi. org/10.1016/S0047-2727(99)00092-4

Windmeijer, F. (2005). A finite sample correction for the variance of linear efficient two-steps GMM estimators. Journal of Econometrics, 126, 25-51. https://doi.org/10.1016/j. jeconom.2004.02.005

Yartey, C.A. (2010). The institutional and macroeconomic determinants of stock market development in emerging economies. Applied Financial Economics, 20(21), 1615-1625. https://doi.org/10.1080/09603107.2010.522519 